\title{
Alternative hosts of Cowpea aphid-borne mosaic virus (CABMV) in sesame (Sesamum indicum) crops grown in Paraguay
}

\author{
Luis R. González-Segnana ${ }^{1}$, Arnaldo Esquivel Fariña ${ }^{1}$, Diego D. González ${ }^{1}$, Ana Paula O. A. Mello ${ }^{2}$, Jorge
} A. M. Rezende ${ }^{2}$ \& Elliot W. Kitajima²

${ }^{1}$ Facultad de Ciencias Agrarias, Universidad Nacional de Asunción, San Lorenzo, Paraguay; ${ }^{2}$ Departamento de Fitopatologia e Nematologia, Escola Superior de Agricultura Luiz de Queiroz, Universidade de São Paulo, Cx. Postal 9, 13418-900 Piracicaba, SP, Brazil

Author for correspondence: Luis R. González-Segnana, email: biotecno@agr.una.py

\begin{abstract}
Sesame (Sesamum indicum L.) production in Paraguay has been severely affected by infection with Cowpea aphid-borne mosaic virus (CABMV), which causes a disease known locally as ka'are. Because very little is known about the epidemiology of this disease, a survey was performed in fields surrounding affected sesame plantations to identify CABMV-infected plants that may be acting as sources of inoculum. Samples from 48 plant species (symptomatic or asymptomatic, mostly spontaneous and a few cultivated) belonging to 17 families were evaluated by biological and serological assays. In a few select cases, confirmation of the infection was achieved by RT-PCR. The following species were found to be naturally infected by CABMV: Amaranthus hybridus, Arachis hypogaea, Crotalaria incana, Crotalaria juncea, Crotalaria spectabilis, and Vigna unguiculata. The absence of resistant/tolerant sesame cultivars along with the ineffectiveness of disease control through the chemical control of aphid vectors indicates that the only alternative available for disease management at present is the elimination and/or reduction of the sources of inoculum immediately before starting new plantations.
\end{abstract}

Key words: Potyvirus, epidemiology, ka'are.

Sesame (Sesamum indicum L.) is an ancient oleaginous plant, and its cultivation dates back thousands of years to Egypt, central Asia, Iran, and China (Weiss, 1983). In Paraguay, sesame cultivation is recent and is mostly performed by small growers. Sesame crops cover nearly 70,000 ha including 41,000 properties, most of which are in the Departamentos of San Pedro, and Concepción (Vasquez, 2011 ), with an average yield of $800 \mathrm{~kg} / \mathrm{ha}$. Nearly $100 \%$ of Paraguayan sesame production is exported.

Sesame production in Paraguay has been affected by many factors; among these, a viral disease known locally as "ka'are" has been causing major and sometimes total losses for producers. The name of this disease is derived from the Guaraní language because affected sesame plants, with shorter internodes and thinner leaf blades, begin to resemble ka'are (Chenopodium ambrosioides L.) plants. The causal agent was identified as an isolate of the Cowpea aphid-borne mosaic virus (CABMV) (González-Segnana et al., 2011). However, little is known about the epidemiology of ka'are disease in Paraguay.

Sesame has a very short cultivation period of approximately three to four months in the summer. Field observations clearly indicate that the virus is transmitted by aphids from nearby spontaneous or cultivated plants infected with the potyvirus. To better understand the epidemiology of this disease before proposing control measures, a survey was carried out in fields surrounding affected sesame plantations to identify CABMV-infected plants that may be acting as sources of inoculum.

Meticulous surveys were performed in eight different parcels (four in the 2010/11 season and four in the 2011/12 season) of sesame crops of approximately one ha each, with priority given to those showing "ka'are" symptoms and those colonized by aphids. Growers were selected from the city of Liberación and the districts of Morumbi 1, San Francisco, San Rafael, and Barrio San Pedro of the District de Guayaybi, Departamento de San Pedro. Additionally, inspections and samplings were performed during the sesame growth season in the following areas: (1) experimental field of Instituto Paraguayo de Tecnologia Agropecuaria (IPTA), district of Choré, Departamento de San Pedro; (2) experimental field of the Servicio de Extensión Agropecuario (SEAP) of the Associación de Servicios de Cooperación Indigena Menonita (ASCIM) and small properties at Yalve Sanga, Distric de Loma Plata, Departamento de Boquerón; and (3) experimental fields of the Facultad de Ciencias Agrárias (FCA), Univerisdad Nacional de Assunción (UNA), San Lorenzo, Departamento Central.

The collected samples were kept in plastic bags, classified, numbered and taken to the laboratory of the 
Departamento de Biologia, FCA, UNA for plant species identification and further detection of CABMV. A total of 43 plant species (mostly spontaneous and a few cultivated) belonging to the following 17 families were collected: Amaranthaceae (Amaranthus hybridus L., A. retroflexus L., Gomphrena sp.); Asteraceae (Acanthospermum hispidum DC., Bidens pilosa L., Conyza bonaerensis (L.) Cronquist., C. canadensis (L.) Cronquist., Gnaphalium pensylvanicum Willd., G. spicatum Mill., Porophyllum ruderale (Jacq.) Cass., Pterocaulon sp., Chrysolaena cognata (Less.); Boraginaceae (Heliotropium indicum L.); Capparaceae (Hemiscolaaculeata (L.)Raf.);Commelinaceae(Commelina diffusa Burm.f.); Convolvulaceae (Ipomoea nil (L.) Roth); Cucurbitaceae (Cucurbita ficifolia Bouché, C. pepo L.); Euphorbiaceae (Euphorbia hyssopifolia L., E. heterophylla L.); Fabaceae (Arachis hypogaea L., Cajanus cajan (L.) Huth, Canavalia ensiformis (L.) DC., Crotalaria incana L., C. juncea L., C. spectabilis L., Glycine max (L.) Merr., Macroptilium atropurpureum (Sessé \& Moc. Ex DC.) Urb., Mimosa debilis Humb. \& Bonpl. Ex Willd., Styzolobium cinerum Piper \& Tracy, Phaseolus vulgaris L., Pueraria thunbergiana Benth., Senna obtusifolia (L.) H.S. Irwin \& Barneby, S. occidentalis (L.) Link, Vigna unguiculata (L.) Walp.); Lamiaceae (Leonurus sibiricus L.); Malvaceae (Corchorus olitorius L., Malvastrum coromandelianum (L.) Garcke, Sida cordifolia L., S. rhombifolia L.); Nyctaginaceae (Boerhavia diffusa L.); Onagraceae (Ludwigia tomentosa (Cambess.) H. Hara); Passifloraceae (Passiflora edulis Sims); Portulacaceae (Portulaca oleracea L., Talinum paniculatum (Jacq.) Gaertn.); Rubiaceae (Richardia brasiliensis Gomes); and Solanaceae (Physalis viscosa L., Solanum sisymbriifolium Lam.). Of these 43 species, some showed symptoms suggesting viral infection (mosaic, leaf deformation, chlorosis, and stunting), whereas others showed no symptoms.

Mechanical transmission assays were performed to recover CABMV from all sampled plants. Extracts from these plants were prepared by grinding leaves in a mortar in the presence of $0.01 \mathrm{M}$ phosphate buffer $(\mathrm{pH}$ 7.0 ) with $0.1 \%$ sodium sulfite. The extracts were then applied manually to the leaf surface of indicator plants (Chenopodium amaranticolor Coste \& Reyn., cowpea ( $V$. unguiculata Wallp.), and sesame) previously dusted with carborundum. Three newly developed plants of each species were inoculated with each sample.

PTA-ELISA was used to detect CABMV in each of the sampled field plants and the mechanically inoculated testplants as described by Mowat \& Dawson (1987). The antiserum (anti-CABMV) was produced against a passionflower isolate (CABMV-P) by one of the authors (JAMR, unpublished data) and used at a 1:1000 dilution. The reaction was considered positive when the $\mathrm{OD}_{405 \mathrm{~mm}}$ reading was at least three times that of the control (uninfected) sample, and a Perlong model DNM 9602 ELISA reader was used to perform the measurements. The reagents were acquired from Sigma Aldrich. The immunoassays were carried out at FCA/UNA.
Some of the collected samples were analyzed by transmission electron microscopy (TEM) to complement the detection of CABMV either by the examination of negatively stained extracts or observation of the cytopathic effects in thin sections as described elsewhere (Kitajima \& Nome, 1999). Examinations were made in a Zeiss EM 900 or JEOL 1011 transmission electron microscopes at ESALQ/ USP, and images were recorded digitally. Uninfected leaf tissues were examined as controls. The tissues were fixed at FA/UNA and subsequently processed and examined at the Electron Microscope Center of ESALQ/USP.

Total RNA was extracted from experimentally infected tissue of groundnut (A. hypogaea), A. hybridus, and $C$. juncea with Trizol Reagent (Invitrogen), according to the manufacturer's recommendations and subsequently used for cDNA synthesis by RT-PCR using M-MLV Reverse Transcriptase (Promega) and Taq DNA Polymerase (Invitrogen), according to the manufacturers' recommendations. CABMV-P1 and CABMV-P2 primers (formerly referred to as PWV-P1 and PWV-P2), which flank the coat protein gene and amplify a fragment of approximately $800 \mathrm{bp}$, were used for RT-PCR (Trevisan et al., 2006). The amplified DNA fragments were visualized on a $1 \%$ agarose gel with SYBR safe under UV light. A 1 $\mathrm{Kb}$ DNA Ladder (Promega) was used as the standard. The RNA extraction was performed at FA/UNA, and the RTPCR was performed at ESALQ/USP.

Table 1 shows the results of the mechanical transmission assays from sampled plants to indicator plants, which were performed from 2010 to 2012. Leaf extracts from the field species $A$. hybridus, groundnut, Crotalaria incana, C. juncea, C. spectabilis, and cowpea, which showed mosaic symptoms, induced local chlorotic lesions in C. amaranticolor and systemic infections in cowpea and sesame. On the other hand, mechanical inoculation of extracts from the symptomatic field species Commelina diffusa, Cucurbita ficifolia, Mucuna ceniza, passionflower (Passiflora edulis), Senna obtusifolia, and Talinum paniculatum resulted only in localized chlorotic lesions in C. amaranticolor. These samples did not react with anti-CABMV serum in ELISA. Thus, the lesions might have been caused by another virus. Extracts from the remaining species collected in the field tested negative in PTA-ELISA with antiserum against CABMV and did not induce symptoms in the three mechanically inoculated test plants.

Negatively stained extracts from some of the field samples (cowpea and C. juncea) and indicator plants that were systemically infected upon mechanical inoculation (cowpea and sesame) contained elongated flexuous particles approximately $700-800 \mathrm{~nm}$ long that resembled potyvirus. Examination of the thin sections of cowpea and sesame inoculated with extracts from infected field plants (including $C$. juncea, $C$. incana, groundnut and A. hybridus) revealed characteristic lamellar inclusions typical of potyvirus infection (Figure 1), such as those induced by other isolates of CABMV. These inclusions appeared as parallel lines or pinwheel configurations (type 
Alternative hosts of Cowpea aphid-borne mosaic virus (CABMV) in sesame (Sesamum indicum)...

TABLE 1 - Plant species from which leaf extracts induced symptoms in mechanically inoculated indicator plants. Systemic infection with CABMV was confirmed by PTA-ELISA

\begin{tabular}{|c|c|c|c|c|c|}
\hline $\begin{array}{l}\text { Symptomatic host } \\
\text { species }\end{array}$ & Family & $\begin{array}{l}\text { Chenopodium } \\
\text { amaranticolor }\end{array}$ & $\begin{array}{c}\text { Vigna } \\
\text { unguiculata }\end{array}$ & $\begin{array}{c}\text { Sesamum } \\
\text { indicum }\end{array}$ & $\begin{array}{l}\text { PTA- } \\
\text { ELISA }\end{array}$ \\
\hline Amaranthus hybridus & Amaranthaceae & $\mathrm{cll}^{1}$ & $\mathrm{~s}$ & $\mathrm{~s}, \mathrm{fd}$ & + \\
\hline Crotalaria incana & Fabaceae & cll & $\mathrm{s}$ & $\mathrm{s}, \mathrm{fd}$ & + \\
\hline C. spectabilis & Fabaceae & cll & s & $\mathrm{s}, \mathrm{fd}$ & + \\
\hline C. juncea & Fabaceae & cll & $\mathrm{s}$ & $\mathrm{s}, \mathrm{fd}$ & + \\
\hline Arachis hypogaea & Fabaceae & cll & s & $\mathrm{s}, \mathrm{fd}$ & + \\
\hline Vigna unguiculata & Fabaceae & cll & $\mathrm{s}$ & $\mathrm{s}, \mathrm{fd}$ & + \\
\hline Talinum paniculatum & Portulacaceae & cll & ns & ns & - \\
\hline Commelina diffusa & Commelinaceae & cll & ns & ns & - \\
\hline Senna obtusifolia & Fabaceae & cll & ns & $\mathrm{ns}$ & - \\
\hline Styzolobium cinerum & Fabaceae & cll & ns & ns & - \\
\hline Passiflora edulis & Passifloraceae & cll & $\mathrm{ns}$ & $\mathrm{ns}$ & - \\
\hline Cucurbita ficifolia & Cucurbitaceae & cll & ns & $\mathrm{ns}$ & - \\
\hline
\end{tabular}

${ }^{1}$ cll, chlorotic local lesions; s, systemic infection; fd, foliar deformation; ns, no symptoms.

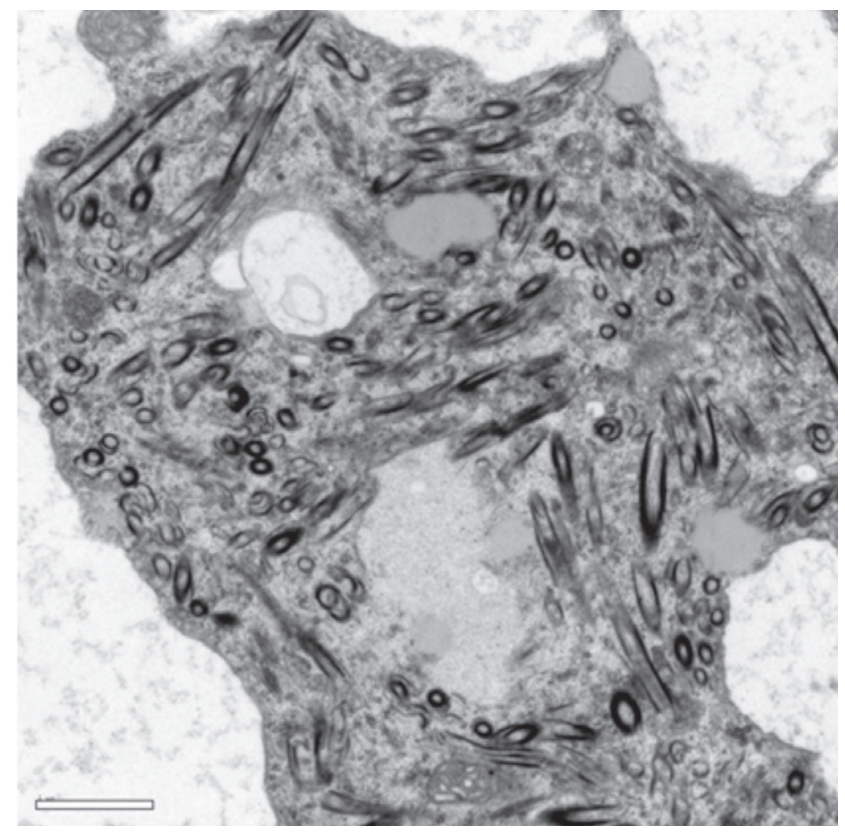

FIGURE 1 - Transmission electron micrograph of a cowpea (Vigna unguiculata) leaf parenchyma cell exhibiting mosaic symptoms after mechanical inoculation with a field sample of Crotalaria juncea, which exhibited mosaic symptoms and grew in the vicinity of sesame (Sesamum indicum) with ka'are symptoms. Note the cytoplasmic type I lamellar inclusion bodies (Edwardson's classification system).

I in the classification system of Edwardson (1974) in the cytoplasm of mesophyll parenchymal and epidermal cells. In some cells, small aggregates of thin slender particles, presumed to represent potyvirus virions, were also observed.

Amplicons of approximately $800 \mathrm{bp}$ were amplified from total RNA extracted from experimentally infected A. hybridus, groundnut, and C. juncea tissues (Figure 2).
The partial host range of CABMV, which was mainly experimentally identified, is already known, and most of the species systemically infected with this potyvirus belong to the Passifloraceae (Maciel et al., 2009) and Fabaceae families. When examining members of the latter family, Bock \& Conti (1974) reported systemic infection in soybean (Glycine max) and petunia (Petunia hybrida) as well as some cultivars of common bean (Phaseolus vulgaris L.) and pea (Pisum sativum L.). Experimental transmission of a potyvirus isolated from passionflower, previously misidentified as Passion fruit woodiness virus (PWV) but then correctly identified as CABMV (Nascimento et al., 2006), caused systemic infection in groundnut, Canavalia ensiformis, $C$. brasiliensis, Senna occidentalis, Centrosema pubescens Benth., C. juncea, zucchini (Cucurbita pepo L. cv. Caserta), and common bean (cvs. Preto G-2 and Black Turtle 2) (Gioria \& Rezende, 1996; Gioria et al., 2004). A CABMV isolate found in beach bean (Canavalia rosea (Sw.) DC.) field plants showing mosaic symptoms was mechanically transmitted and caused systemic infection in Cajanus cajan (L.) Millsp., beach bean, Canavalia ensiformis, soybean (cv. Santa Rosa), Senna occidentalis, sesame, cowpea, Vigna radiata, and Nicotiana benthamiana Domin. but did not infect groundnut or the common bean cvs. Jalo, Carioca and Black Turtle 2 (Kitajima et al., 2008). There are some previous reports of CABMV that naturally infects sesame in Georgia, USA (Pappu et al., 1997). Additionally, a potyvirus (potentially CABMV) reportedly infected an experimental sesame field in Ceará state, Brazil (Lima et al., 1991).

Natural CABMV infection was noted in 12 species, the majority of which (seven) were members of the Fabaceae family. This finding corroborates some of the above experimental results and reveals additional host for this potyvirus in the family Amaranthaceae, which was not previously reported as having susceptible species. Furthermore, this appears to be the first observation of a 


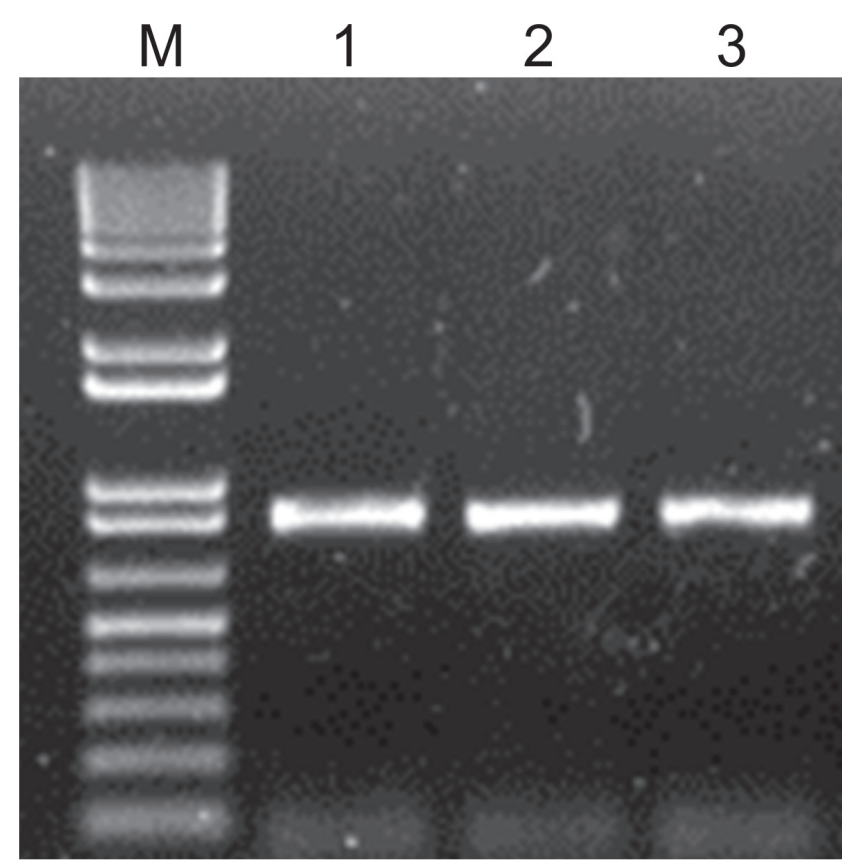

FIGURE 2 - Gel electrophoresis ( $0.8 \%$ agarose) of the RT-PCR products amplified using the primers CABMV-P1 and CABMVP2. M, Marker (1 Kb DNA ladder); 1, Arachis hypogaea; 2, Crotalaria juncea; 3, Amaranthus hybridus.

large number of naturally CABMV-infected species next to sesame crops in the field. These facts suggest that the high incidence of this virus in sesame plantations, which was first reported in Paraguay by González-Segnana et al. (2011), may be partially associated with large numbers of CABMV sources in sesame-producing regions. The absence of resistant/tolerant sesame cultivars and the ineffectiveness of disease control through the chemical control of aphid vectors (due to the non-persistent virus/ vector relationship) indicate that the only alternative available for disease management at the moment is the elimination and/or reduction of sources of inoculum before starting new plantations. Another strategy would be to reduce infestation by exogenous viruliferous aphids using physical barriers. Failure to adopt these procedures may result in a constant increase in inoculum pressure, which will certainly contribute to early infection of large number of plants, resulting in severe yield losses.

\section{ACKNOWLEDGMENTS}

The authors are grateful for financial support received from INBIO, and to Dr. Gerson Oliveira Romão, Departamento de Ciências Biológicas, ESALQ/USP for revising the names and classification of the species of test plants.

\section{REFERENCES}

Bock KR, Conti M (1974) Cowpea aphid borne mosaic virus. Description of Plant Viruses No. 134. Kew UK. CMI/AAB.

Edwardson JR (1974) Some properties of the Potato virus Y group. Gainesville FL, USA. Florida Agricultural Experimental Station. Monograph Series No. 4.

Gioria R, Rezende JAM, Kitajima EW (2004) Caracterização biológica, sorológica e molecular de uma estirpe do Passion fruit woodiness virus (PWV) causadora de mosqueado em algumas cucurbitáceas. Summa Phytopathologica 30:256-264.

Gioria R, Rezende JAM (1996) Reação de diferentes espécies, principalmente de leguminosas, a seis isolados do vírus do endurecimento dos frutos do maracujazeiro. In: IV Simpósio de Iniciação Científica da Universidade de São Paulo, Resumos... Piracicaba SP. ESALQ/USP. p.437.

Gonzáles-Segnana L, Ramirez de Lopez M, Mello APOA, Rezende JAM, Kitajima EW (2011) First report of Cowpea aphid borne mosaic virus in sesame in Paraguay. Plant Disease 95:613.

Kitajima EW, Alcantara BK, Madureira PM, Alfenas-Zerbini P, Rezende JAM, Zerbini FM (2008) A mosaic of beach bean (Canavalia rosea) caused by an isolate of Cowpea aphid borne mosaic virus (CABMV) in Brazil. Archives of Virology 153:743-747.

Kitajima EW, Nome SF (1999) Microscopia eletronica en virología vegetal. In: Docampo DM, Lenardon SL (Ed.) Métodos para detectar patógenos sistémicos. Córdoba Agentina. INTA/IFFYVE-JICA. pp. 59-87.

Lima JAA, Silveira LFS, Santos CDG (1991) Infecção natural em gergelim ocasionada por um potyvirus. Fitopatologia Brasileira 16:60-62.

Maciel SC, Nakano DH, Rezende JAM, Vieira MLC (2009) Screening of Passiflora species for reaction to Cowpea aphid-borne mosaic virus reveals an immune wild species. Scientia Agricola 66:414-418.

Mowat WP, Dawson S (1987) Detection of plant viruses by ELISA using crude sap extracts and unfractionated antisera. Journal of Virological Methods 15:233-247.

Nascimento AVS, Santana EN, Braz ASK, Alfenas PF, Pio-Ribeiro G, Andrade GP, Carvalho MG, Zerbini FM (2006) Cowpea aphidborne mosaic virus (CABMV) is widespread in passionfruit in Brazil and causes passionfruit woodiness disease. Archives of Virology 151:1797-1809.

Pappu HR, Pappu SS, Sreenivasulu P (1997) Molecular characterization and interviral homologies of a potyvirus infecting sesame (Sesamum indicum) in Georgia. Archives of Virology 142:1921-1927.

Trevisan F, Mendes BMJ, Maciel SC, Vieira MLC, Meletti LMM, Rezende JAM (2006) Resistance to Passion fruit woodiness virus in transgenic passionflower expressing the virus coat protein gene. Plant Disease 90:1026-1030.

Vazquez F (2011) Atlas Agropecuario y Forestal del Paraguay. Assuncion Paraguay. UGP.

Weiss EA (1983) Sesame. In: Weiss EA (Ed.) Oilseed crops. London UK. Logman. pp. 282-340.

TPP 2013-0069 - Received 7 May 2013 - Accepted 23 July 2013 Section Editor: F. Murilo Zerbini 